\title{
Assessment of the Influence of Meteorological Factors and Agricultural Background on the Productivity of Spring Wheat Ulyanovskaya 105 in the Predkamye of the Republic of Tatarstan
}

\author{
Igor Serzhanov*, Farit Shaikhutdinov, Razil Garayev and Albina Serzhanova \\ Kazan State Agrarian University, 65, K. Marx st., 420015, Kazan, Russia
}

\begin{abstract}
The most valuable and widespread food crop is spring wheat. Soil and climatic conditions influence the grain productivity and quality. The grain quality is affected by air humidity, insolation, nitrogen content in the soil and agricultural technologies. In 2019-2020, on the experimental field of the agronomic faculty of Kazan State Agrarian University, studies aimed to identify the reaction of the Ulyanovskaya 105 spring soft wheat to meteorological conditions and agricultural background were carried out. The soil was light gray forest, medium loamy. The predecessor was winter rye after pure fallow. Meteorological conditions were favorable for the growth and development of spring wheat. In 2019, the HMC was 1.36, in $2020-1.13$. The maximum yield in 2019 and in 2020 was obtained with the application of calculated doses of fertilizers when sowing 6 million viable seeds per hectare $-3.0-3.44$ tons and 3.67-4.21 tons per hectare.
\end{abstract}

\section{Introduction}

One of the most important tasks of agriculture in the Russian Federation is to increase the volume of grain production and improve its quality. It becomes important to develop the adaptive crop production based on highly productive agrocenoses through the introduction of new varieties that rationally use agro-climatic conditions of the region [1, 4-6].

An increase in the number of varieties is a condition for expanding the sown areas of spring wheat in the Middle Volga region [2, 3, 8].

In the Republic of Tatarstan, spring soft wheat is the main grain crop; therefore, the development of methods for increasing its yield is important for the sustainable development of the crop production industry. The annual demand for food grain is more than 350 thousand tons, and it is fully satisfied by agricultural enterprises of Tatarstan.

At the same time, it is necessary to improve the quality characteristics of grain; the technology for the production of spring wheat is of great practical importance [7]. In recent years, in the agrotechnology of agricultural crops, the methods of crop management (the use of differentiated seeding rates, fertilizers) are important $[9,10]$.

\section{Methods}

The object of research was spring wheat Ulyanovskaya 105. The experiments were carried out in 2019-2020 on light gray forest soils. The humus content in the $0-20 \mathrm{~cm}$ layer was 3.2-3.4 \% (according to Tyurin), mobile phosphorus - 245-250 mg, exchangeable potassium 138-140 mg per $1000 \mathrm{~g}$ of soil (according to Kirsanov), salt $\mathrm{pH}-$ second extract $-5.8-6.1$; acidity was close to neutral.

The experiments were conducted according to the following scheme:

I - nutritional level (background) - natural background without fertilizers (control).

II - nutritional level (background) NPK for 3 tons of grain per hectare.

III - nutritional level (background) NPK for $4 \mathrm{t}$ of grain per hectare.

At each nutritional level, four seeding rates were used $-4 ; 5 ; 6$ and 7 million viable seeds per hectare.

The experiment was repeated four times, the location of the plots was one-tier, randomized. The total area of the plots was $40 \mathrm{~m}^{2}$, the accounting area was $36 \mathrm{~m}^{2}$.

The predecessor was winter rye after fallow Plowing with preliminary stubble plowing was carried out in the third decade of August. Fertilizers were calculated by the calculation-balance method and were applied in doses of three tons - N63P45K30, 4 t - N89-96P71-77K57-63.

The first-class seeds were sown after the pre-sowing cultivation on May 4 in 2019 and on May 5 in 2020. The crop was treated in accordance with the progressive technology of spring wheat cultivation. Harvesting was carried out in the phase of full ripeness using the SAMPO-500 combine.

\footnotetext{
* Corresponding author: igor.serzhanov@mail.ru
} 


\section{Results and discussion}

In 2019-2020, the agrometeorological conditions were favorable for the development of the crop (Fig. 1).

An assessment of the meteorological elements showed their significant variability. The temperature regime and moisture content reflected peculiarities of the region, some periods were characterized by insufficient moisture and air droughts, while others were characterized by excessive moisture and droughts. This made it possible to reveal the reaction of the research object to the factors under study, the SCC for the growing season of 2019 was 1.36 , and in $2020-1.13$ (Table 1).

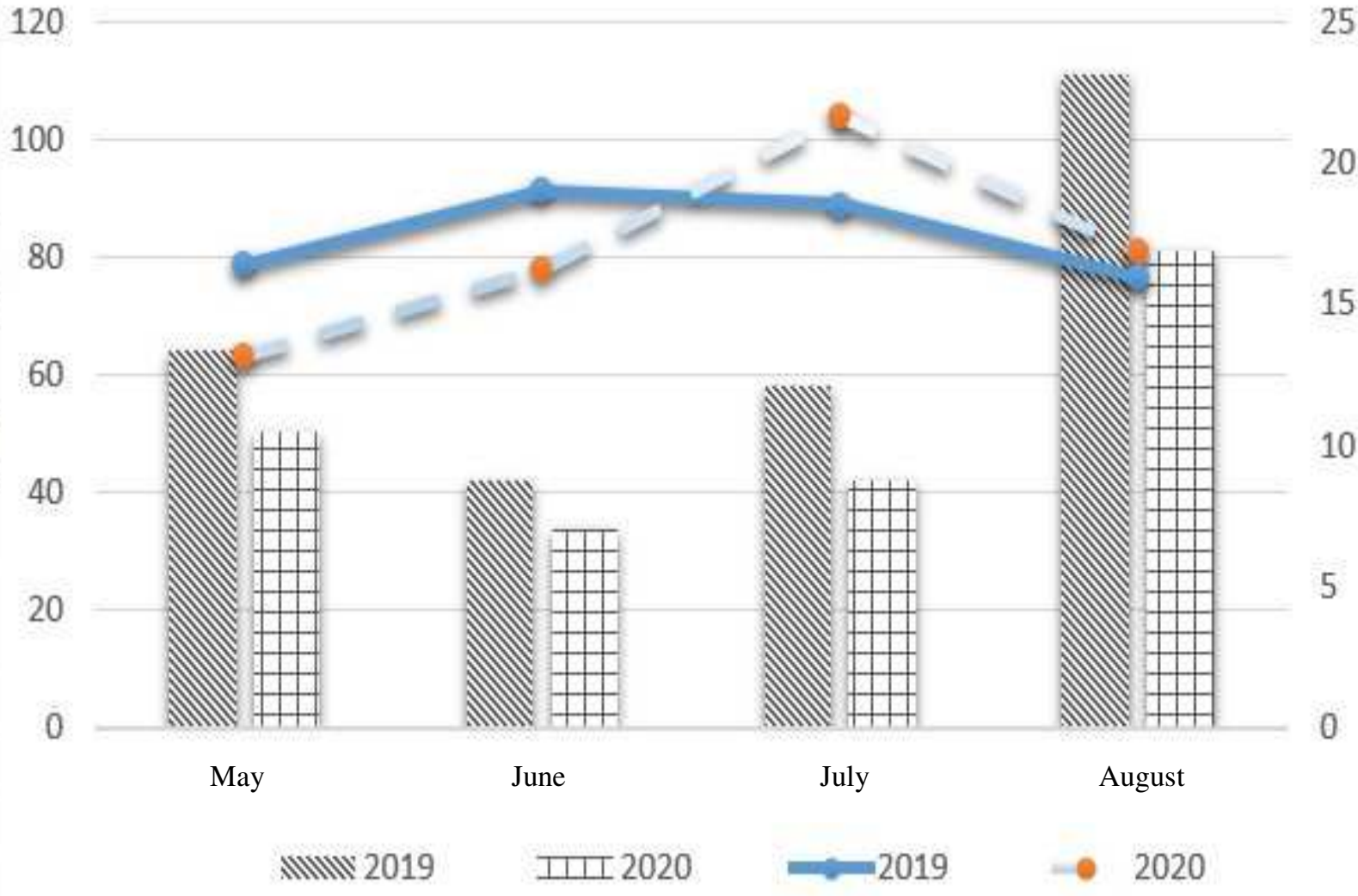

Fig. 1. Meteorological conditions for the growing season of spring wheat (according to the agrometeopost "Kabany" of the Laishevsk district of the Republic of Tatarstan)

Table 1. The GTC value during the spring wheat growing season for 2019 and 2020

\begin{tabular}{|c|c|c|c|c|c|c|c|c|c|c|c|c|}
\hline \multirow[t]{3}{*}{ Years } & \multicolumn{12}{|c|}{ Months and decades } \\
\hline & \multicolumn{3}{|c|}{ May } & \multicolumn{3}{|c|}{ June } & \multicolumn{3}{|c|}{ July } & \multicolumn{3}{|c|}{ August } \\
\hline & I & II & III & I & II & III & $\mathbf{I}$ & II & III & I & II & III \\
\hline 2019 & 0.56 & 1.96 & 1.33 & 0.66 & 0.22 & 1.31 & 0.56 & 0.69 & 1.92 & 6.08 & 0.55 & 0.92 \\
\hline 2020 & 0.64 & 2.89 & 0.70 & 1.98 & 0.11 & 0.04 & 0.41 & 0.05 & 1.67 & 2.04 & 2.81 & 0.22 \\
\hline Average for 2019-2020 & 0.60 & 2.43 & 1.02 & 1.32 & 0.17 & 0.68 & 0.49 & 0.60 & 1.78 & 4.06 & 1.68 & 0.57 \\
\hline
\end{tabular}

Unequal conditions of temperature and water regimes had a significant impact on the emergence of spring wheat seedlings. The seeds sown on May 4 in 2019 formed full shoots on May 12. With an average daily temperature of $16.40 \mathrm{C}$ in May, $147.6{ }^{\circ} \mathrm{C}$ was required for the emergence of seedlings. In 2020, the seeds were sown on May 5, and full shoots were observed on May 17, since the thermal regime during germination and emergence was significantly lower. From sowing to full sprouting, $170.3{ }^{\circ} \mathrm{C}$ heat was required. The period from full sprouting to tillering was favorable in terms of moisture supply and thermal regime of the soil [HMC was 1.64-1.79]. Spring wheat plants went through stages II-IV of organogenesis. From germination to the beginning of tillering, $229.6{ }^{\circ} \mathrm{C}$ of heat were required in 2019 and $210^{\circ} \mathrm{C}$ in 2020 . In 2019 , the duration of the period from tillering to stemming was 12 , and in 2020 14 days; $210-227^{\circ} \mathrm{C}$ of heat were required at a HMC of 0.88-1.0. One of the reasons for the formation of a lower grain yield in 2019 is a lower hydrothermal coefficient in the shooting phase.

The issue of duration of the growing season for spring wheat is of great importance, since an excessive delay in the growth and development of wheat can adversely affect its yield and quality.

Phenological observations made it possible to trace the duration of the growing season of. The duration of 
the full cycle of (sowing-full ripeness) was 89 days in 2019 and 93 days in 2020.

Nutritional backgrounds did not have a significant effect on the phenological phases and the length of the growing season of spring wheat. Wheat ripening was slower (by 1-2 days). The duration of individual interphase periods and the length of the growing season was influenced by the seeding rate. On all nutrition backgrounds, a slower development of plants was observed with an increase in the area of nutrition, that is, a decrease in seeding rates. Changes in the duration of interfacial periods were observed after shooting, earing, and before full ripeness.

The study of stand density showed that the soil and climatic conditions of the Predkamsk zone of the Republic of Tatarstan did not have a great influence on the level of field germination of spring wheat. Observations of the completeness of spring wheat seedlings showed that on all nutrition backgrounds with an increase in the seeding rate from 4 to 7 million, field germination decreased (Table 2).

Table 2. The complex effect of fertilizers and various seed sowing rates on the field germination and preservation of spring wheat Ulyanovskaya 105 (2019-2020)

\begin{tabular}{|c|c|c|c|c|c|c|}
\hline \multirow[t]{2}{*}{ Fertilizers } & \multirow{2}{*}{$\begin{array}{l}\text { Seeding } \\
\text { rates, } \\
\text { mln., pcs }\end{array}$} & \multicolumn{2}{|c|}{ Full germination } & \multicolumn{3}{|c|}{ Preservation of plants until full ripeness } \\
\hline & & $\begin{array}{c}\text { number of } \\
\text { plants, } \\
\text { m2, pes. }\end{array}$ & $\begin{array}{c}\text { field } \\
\text { germinat } \\
\text { ion, } \%\end{array}$ & $\begin{array}{c}\text { number of } \\
\text { plants, m2, } \\
\text { pcs. }\end{array}$ & $\begin{array}{l}\% \text { of the } \\
\text { number } \\
\text { of shoots }\end{array}$ & $\begin{array}{l}\% \text { of the } \\
\text { number } \\
\text { of seeds }\end{array}$ \\
\hline Control & $\begin{array}{l}4 \\
5 \\
6 \\
7\end{array}$ & $\begin{array}{l}322 \\
383 \\
440 \\
493\end{array}$ & $\begin{array}{l}80.5 \\
76.5 \\
73.3 \\
70.4\end{array}$ & $\begin{array}{l}300 \\
363 \\
392 \\
424\end{array}$ & $\begin{array}{l}93.0 \\
98.7 \\
89.0 \\
86.0\end{array}$ & $\begin{array}{l}75.0 \\
72.6 \\
65.3 \\
60.6\end{array}$ \\
\hline $\begin{array}{c}\text { NPK for } 3 \text { tons } \\
\text { of grain from } \\
1 \text { hectare }\end{array}$ & $\begin{array}{l}4 \\
5 \\
6 \\
7\end{array}$ & $\begin{array}{l}320 \\
384 \\
441 \\
490\end{array}$ & $\begin{array}{l}80.0 \\
76.8 \\
73.5 \\
70.0\end{array}$ & $\begin{array}{l}304 \\
356 \\
402 \\
434\end{array}$ & $\begin{array}{l}95.0 \\
92.7 \\
91.1 \\
88.6\end{array}$ & $\begin{array}{l}76.0 \\
71.2 \\
67.0 \\
62.0\end{array}$ \\
\hline $\begin{array}{l}\text { NPK for } 4 \text { tons } \\
\text { of grain from } \\
1 \text { hectare }\end{array}$ & $\begin{array}{l}4 \\
5 \\
6 \\
7\end{array}$ & $\begin{array}{l}325 \\
383 \\
437 \\
489\end{array}$ & $\begin{array}{l}81.4 \\
76.5 \\
72.8 \\
69.9\end{array}$ & $\begin{array}{l}308 \\
358 \\
403 \\
435\end{array}$ & $\begin{array}{l}94.7 \\
93.4 \\
92.2 \\
88.9\end{array}$ & $\begin{array}{l}77.0 \\
71.6 \\
67.2 \\
62.1\end{array}$ \\
\hline
\end{tabular}

On average, with crop thickening by increasing the seeding rate from 4 to 7 million pieces, field germination decreased from 80.5 to $70.4 \%$, in the options with the application of fertilizers - to 80.0-70.0 and 81.4 and $69.9 \%$. A decrease in seed germination with a decrease in the feeding area is due to the deterioration of conditions for germination and formation of full-fledged shoots.
The safety of plants slightly increased when applying fertilizers. Plant loss decreased by 2.1-3.2\% compared to the control option. On all nutrition backgrounds, as the sowing thickened by increasing the seeding rate, the survival rate decreased, in the control option it decreased from 93.0 to $86.0 \%$, on the calculated backgrounds from $95.0-88.6$ and $94.7-88.9 \%$.

Table 3. The complex effect of fertilizers and seeding rates on the yield of spring wheat Ulyanovskaya 105

\begin{tabular}{|c|c|c|c|c|c|c|}
\hline \multirow{2}{*}{ Fertilizer (A) } & \multirow{2}{*}{$\begin{array}{c}\text { Seeding rates, } \\
\text { mln, pcs }\end{array}$} & \multicolumn{2}{|c|}{ Yield, t/ha } & \multirow{2}{*}{$\begin{array}{l}\text { Average for } \\
\text { two years }\end{array}$} & \multicolumn{2}{|c|}{ Increase in yield, t/ha } \\
\hline & & 2019 & 2020 & & fertilization & $\begin{array}{c}\text { Seeding } \\
\text { rate }\end{array}$ \\
\hline Control & $\begin{array}{l}4 \\
5 \\
6 \\
7\end{array}$ & $\begin{array}{l}1.86 \\
2.09 \\
2.10 \\
1.93 \\
\end{array}$ & $\begin{array}{l}2.16 \\
2.49 \\
2.39 \\
2.31\end{array}$ & $\begin{array}{l}2.01 \\
2.29 \\
2.24 \\
2.12\end{array}$ & $\begin{array}{l}- \\
- \\
- \\
-\end{array}$ & $\begin{array}{l}- \\
0.28 \\
0.23 \\
0.11\end{array}$ \\
\hline $\begin{array}{c}\text { NPK for } 3 \text { tons of grain } \\
\text { from } \\
1 \text { hectare }\end{array}$ & $\begin{array}{l}4 \\
5 \\
6 \\
7\end{array}$ & $\begin{array}{c}2.63 \\
2.75 \\
3.0 \\
2.87 \\
\end{array}$ & $\begin{array}{l}3.05 \\
3.14 \\
3.67 \\
3.62 \\
\end{array}$ & $\begin{array}{l}2.84 \\
2.95 \\
3.34 \\
3.24 \\
\end{array}$ & $\begin{array}{l}0.83 \\
0.66 \\
1.10 \\
1.12 \\
\end{array}$ & $\begin{array}{l}- \\
0.11 \\
0.50 \\
0.40\end{array}$ \\
\hline $\begin{array}{c}\text { NPK for } 4 \text { tons of grain } \\
\text { from } \\
1 \text { hectare }\end{array}$ & $\begin{array}{l}4 \\
5 \\
6 \\
7\end{array}$ & $\begin{array}{l}2.92 \\
3.17 \\
3.44 \\
3.38 \\
\end{array}$ & $\begin{array}{l}3.65 \\
3.97 \\
4.21 \\
4.12 \\
\end{array}$ & $\begin{array}{l}3.29 \\
3.57 \\
3.83 \\
3.75\end{array}$ & $\begin{array}{l}1.28 \\
1.28 \\
1.59 \\
1.63 \\
\end{array}$ & $\begin{array}{l}- \\
0.28 \\
0.54 \\
0.46\end{array}$ \\
\hline $\mathrm{LSD}_{05}$ & & $\begin{array}{c}0.40 \\
0.15 \\
\text { A } 0.19 \\
\text { B } 0.09 \\
\text { AB } 0.089\end{array}$ & $\begin{array}{c}0.26 \\
0.079 \\
0.13 \\
0.045 \\
0.05\end{array}$ & & & \\
\hline
\end{tabular}


Agrometeorological conditions prevailingon different backgrounds and areas determined peculiarities of the spring wheat yield. The research results showed that the highest yields were obtained in 2020 compared to 2019, when unfavorable conditions developed during the most critical periods of plant development (Table 3 ).

The studies made it possible to establish that the seeding rates of spring wheat should be differentiated depending on the background of nutrition.

The optimal seeding rates on the gray forest soils of the Predkamye turned out to be 5 million for the unfertilized background (control), and 6 million for the fertilized backgrounds. On average, in the first case, an increase in the yield amounted to 0.28 tons per hectare. Further thickening did not increase the yield. On the fertilized backgrounds, the highest yield was achieved when sowing 6 million seeds per hectare. For the fertilized background, the yield increase was 0.5 tons per hectare or $17.6 \%$, at 5 million - 0,11 tons or $3.9 \%$. For the fertilized background at 4 tons of grain, respectively: with 6 million -0.54 tons or $16.4 \%$, with 5 million 0.28 tons or $8.5 \%$.

Table 4. Influence of the nutritional background on spring wheat grain quality

\begin{tabular}{|c|c|c|c|c|c|c|c|}
\hline Yield & $\begin{array}{c}\text { Seeding } \\
\text { rates, } \\
\text { mln., pcs }\end{array}$ & $\begin{array}{c}\text { mass fraction } \\
\text { of gluten, \% }\end{array}$ & $\begin{array}{c}\text { quality group } \\
\text { according to } \\
\text { IDK-1 }\end{array}$ & $\begin{array}{c}\text { vitreousness, } \\
\text { \% }\end{array}$ & $\begin{array}{c}\text { mass } \\
\text { fraction } \\
\text { of gluten, \% }\end{array}$ & $\begin{array}{c}\text { quality group } \\
\text { according to } \\
\text { IDK-1 }\end{array}$ & $\begin{array}{c}\text { vitreousn } \\
\text { ess, } \\
\text { \% }\end{array}$ \\
\hline Control & 4 & 23.4 & II & 46.4 & 20.9 & II & 44.5 \\
& 5 & 23.0 & II & 46.1 & 20.5 & II & 44.2 \\
& 6 & 22.7 & II & 46.0 & 20.1 & II & 44.0 \\
& 7 & 22.5 & II & 45.8 & 19.8 & II & 43.6 \\
\hline NPK for 3 tons & 4 & 25.5 & II & 53.6 & 23.7 & II & 49.7 \\
of grain from & 5 & 25.2 & II & 53.2 & 23.1 & II & 49.3 \\
1 hectare & 6 & 25.0 & II & 52.7 & 23.0 & II & 49.0 \\
& 7 & 24.7 & II & 52.4 & 22.7 & II & 48.7 \\
\hline NPK for 4 tons & 4 & 25.9 & II & 54.5 & 24.2 & II & 52.7 \\
of grain from & 5 & 25.6 & II & 54.2 & 23.8 & II & 52.4 \\
1 hectare & 6 & 25.3 & II & 54.0 & 23.4 & II & 52.0 \\
& 7 & 25.1 & II & 53.6 & 23.1 & II & 51.8 \\
\hline
\end{tabular}

Table 4 shows that in drier 2019, grain quality indicators on all nutritional backgrounds were higher compared to the similar indicators in 2020 , since during the period of grain filling and ripening, climatic conditions did not favor the accumulation of a sufficiently high amount mass fraction of gluten.

Our studies have confirmed the effectiveness of the use of mineral fertilizers on gray forest soils of the Predkamsk zone of the Republic of Tatarstan. In both years of research, at a seeding rate of 6 million germinating seeds per hectare, the mass fraction of gluten on fertilized backgrounds increased by 2.3-2.6: in $2019-2.9$, and in $2020-3.3 \%$. The quality of gluten corresponded to group II.

The seeding rates also had some effect on the grain quality on all nutrition backgrounds as the seeding rate increased from 4 to 7 million pcs. seeds per hectare, the mass fraction of gluten and grain vitreousness decreased.

\section{Conclusion}

Thus, there is a complex relationship between the meteorological factors, the agricultural background, the seeding rate, yield and the grain quality.

\section{References}

1. L.G. Gaffarova, IOP Conf. Ser. Earth and Envir. Sci., 272 (2019)
2. R.I. Safin, L.Z. Karimova, F.N. Safiollin, Sh.Z. Validov, B.G. Ziganshin, K.Z. Karimov, G.S. Minnullin, E3S Web of Conf., 91, 185-193 (2019)

3. I.D. Davlyatshin, L.G. Gaffarova, IOP Conf. Ser. Earth Envir. Sci., 272, 032096 (2019)

4. F.Sh. Shaikhutdinov, I.M. Serzhanov, A.R. Serzhanova, A.A. Valiev, V.V Aksakova, BIO Web of Conf., 17, 00072 (2020)

5. M.F. Amirov, F.Sh. Shaikhutdinov, I.M. Serzhanov, A.R. Serzhanova, BIO Web of Conf., 17, 00071 (2020)

6. R.V. Minikayev, L.G. Gaffarova, BIO Web of Conf., 17, 00250 (2020)

7. A.M. Sabirzyanov, N.A. Loginov, I.P. Talanov, M.V. Panasyuk, T.G. Hadeyev, IOP Conf. Ser. Earth Envir. Sci, 341, 012027 (2019)

8. F.N. Safiollin, R.M. Nizamov, V.M. Panasyuk, S.R. Suleymanov, A.A. Akhmetzyanov, BIO Web of Conf., 17, 00241 (2020)

9. M.Yu. Gilyazov, F.Sh. Faskhutdinov, R.V. Minikaev, Int. sci. and pract. Conf. Smart solutions for agriculture (AgroSMART), KnE Life Sciences (2019)

10. D.T. Khaliullin, A.V. Dmitriev, Modern high technol., 12-2, 272-276 (2015) 